Ann. Biol, anim. Bioch. Biophys., 1979, 19 (4 B), 1381-1386.

\title{
Ovarian function in rats treated postnatally with progesterone
}

\author{
par J. PRESL, A. BUKOVSKY, Z. KRABEC
}

Institute for the Care of Mother and Child, 14710 Progue 4 Podoli, Czechoslovakia.

Summary. Long-lasting postnatal progesterone treatment in female rats induced an early or delayed ovulatory failure with persistent vaginal estrus whereas short-term administration was ineffective. The beginning and incidence of ovulatory failure appeared to depend on the beginning and duration of the progesterone treatment and on the progesterone dosage. Lowering the latter decreased the full « damaging » activity. Shortening the duration of the effective progesterone dosage induced a delayed ovulatory failure only and finally decreased the incidence of that kind of « damaging » progesterone activity. The necessary duration of progesterone administration for inducing an early ovulatory failure exceeded the early postnatal steroid-sensitive period of sexual differentiation of the hypothalamus. Moreover, long-lasting progesterone treatment resulted in a delayed ovulatory failure even if started after termination of this critical period. We concluded from these results that the noxious and/or protective progesterone effects on the development of the hypothalamic control of gonadotropin secretion in female rats were mediated by extracerebral mechanisms which are thought to be realized through the relationships between the differentiating immune system and the ovary.

Unlike exogenous testosterone or estradiol, both of which masculinize the pattern of hypothalamic control of gonadotropin secretion if administered in newborn female rats (for review see Gorski, 1971), properly timed progesterone treatment protects the developing female brain from the "damaging " effects of early postnatal testosterone or estradiol administration (Takasugi, 1954; Dorfman and Kincl, 1963 ; Shipley and Meyer, 1965 ; Kincl and Maqueo, 1965 ; Cagnoni et al., 1965 ; Arai and Gorski, 1968). High doses of progesterone alone injected during the early post-natal steroid-sensitive (《 critical ») period of hypothalamic sexual differentiation do not impair the cyclic ovulatory release of gonadotropins in adult female rats (Shipley and Meyer, 1962, 1965 ; Kincl et al., 1963 ; Presl et al, 1967 ; Sano, 1970 ; Fels, 1976). However, postnatal long-lasting small-dose progesterone treatment does impair the late ovulatory function in rats (Greene and Burrill, 1941 ; Bukovsky ef al., 1976). We attempted to clarify the effective period of that postnatal progesterone treatment. 


\section{Materials and methods.}

Immature female Wistar rats of our laboratory colony were injected sc once daily with different progesterone doses in oil during different periods of time. The day of birth was considered as day 1 . Two kinds of daily progesterone doses were combined, either the low ones of $100 \mu \mathrm{g}$ and $200 \mu \mathrm{g}$ or the high one of $1200 \mu \mathrm{g}$. The amount of oil solvent was $0.05 \mathrm{ml}$ for ages up to 19 days, and $0.1 \mathrm{ml}$ from the age of 20 days. The details of the experimental procedures in all eleven progesterone-treated groups are presented with the results in figure 1 . The control animals were injected with oil only during the 26 days of life.

Vaginal smears were taken daily during 4 weeks after the 2 nd and the 5 th postnatal month. Only then were the animals decapitated and the ovaries evaluated histologically, using a standard technique.

\section{Results.}

An early ovulatory failure (persistent vaginal estrus observed after the 2 nd postnatal month) was induced with daily progesterone administration up to the 26 th postnatal day (Experiments 1-4). Lowering the daily progesterone dose in the last week of treatment decreased its full « damaging » effect; delayed ovulatory failure (persistent vaginal estrus observed only after the 5th postnatal month) appeared approximately in half of the animals (Experiment 4). Shortening the progesterone treatment to days 10 to 26,1 to 19,1 to 10 or 10 to 19 resulted merely in a delayed

\section{TABLE 1}

Incidence of a persistently estrous type of vaginal smear in rats following different types of postnatal progesterone treatment

\begin{tabular}{|c|c|c|c|}
\hline \multirow{2}{*}{$\begin{array}{c}\text { Experiment, } \\
\text { No. * }\end{array}$} & \multirow{2}{*}{$\begin{array}{l}\text { No. of } \\
\text { rats }\end{array}$} & \multicolumn{2}{|c|}{ Persistently estrous type of smear } \\
\hline & & $\begin{array}{l}\text { 3rd postnatal } \\
\text { month }\end{array}$ & $\begin{array}{l}\text { 6th postnatal } \\
\text { month }\end{array}$ \\
\hline 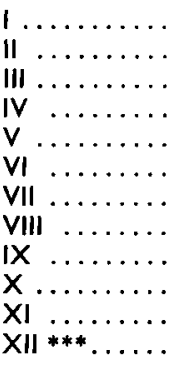 & $\begin{array}{r}6 \\
12 \\
9 \\
23 \\
9 \\
8 \\
5 \\
16 \\
18 \\
15 \\
11 \\
14\end{array}$ & $\begin{array}{c}6 / 6 \\
12 / 12 \\
9 / 9 \\
10 / 23 \\
0 / 9 \\
0 / 8 \\
0 / 5 \\
0 / 16 \\
0 / 18 \\
0 / 15 \\
0 / 11 \\
0 / 14\end{array}$ & $\begin{array}{c}6 / 6 \\
12 / 12 \\
9 / 9 \\
20 / 23 \\
9 / 9 \\
8 / 8 \\
2 / 5 \\
3 / 16 \\
0 / 18 \\
0 / 15 \\
0 / 11 \\
0 / 14\end{array}$ \\
\hline
\end{tabular}

* See Figure 1 for type of progesterone treatment.

** No. of animals with persistent estrus/total number.

*** Control group of animals treated with oil solvent only. 
ovulatory failure with a decreasing effect (Experiments 5-8). Limiting the progesterone treatment to days 20 to 26 , even if combined with an ineffective single high dose of progesterone at the age of 5 days, was completely without effect (Experiments 9-11). A 26-day administration of the oil solvent only, beginning from the 1 st neonatal day, was likewise without effect. The results are summarized in figure 1 and table 1.

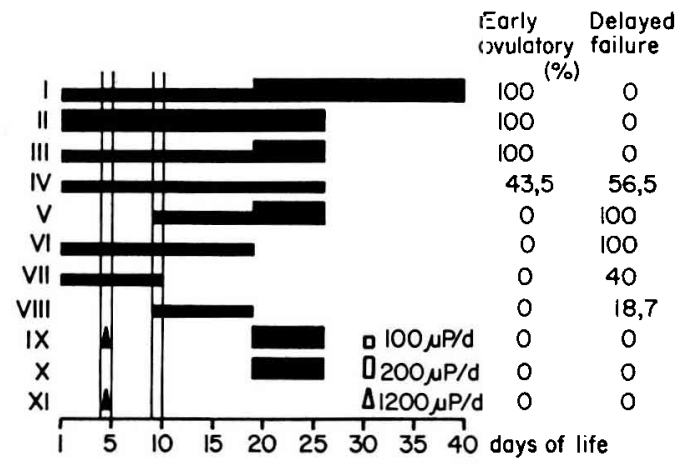

FIG. 1. - Timing, duration and dosage of postnatal progesterone treatment in rats with resulting percentual incidence of ovulatory failure.

In all animals showing persistent vaginal estrus at decapitation, ovaries lacking corpora lutea, and with the frequent presence of thecal hyperplasia, were observed, the latter protruding into the large cavitated follicles with proliferating granulosa.

\section{Discussion.}

During the period of protective and/or noxious action of progesterone a significant uptake of ${ }^{3} \mathrm{H}$-progesterone by the female rat hypothalamus could not be observed in contrast to the pituitary (Presl ef al., 1975a), nor could a decrease in ${ }^{3} \mathrm{H}$-estradiol accumulation in the hypothalamus result following progesterone pretreatment in female rats during the first 10 days of life if radioactivity was measured using a liquid scintillation counter (Presl ef al., 1975b). Similarly, progesterone administration does not change ${ }^{3} \mathrm{H}$-testosterone uptake by the hypothalamus in neonatal female rats (Hefner and Van Tienhoven, 1973). An hypothesis has been expressed, therefore, on the extracerebral mechanism of the protective effect of progesterone (Presl et al., 1975b). So far progesterone has not been found by autoradiography to be concentrated and retained in the nuclei of neurons in the rat brain (Stumpf et al., 1976), although contradictory results have been reported demonstrating estrogen-inducible, specific progesteronebinding protein in the female rat hypothalamus (Kato ef al., 1978). Even if this is the case, then the present failure to show hypothalamic progesterone accumulation during the postnatal steroid sensitive period in female rats would mean that endogenous estrogens are unable to induce detectable progesterone receptors in the hypothalamus. In fact, hight affinity progesterone binding has not been demonstrated in brain cytosols during the early postnatal period in female rats (Greenstein, 1978). Moreover, a significant uptake of ${ }^{3} \mathrm{H}$-progesterone by the ovaries could not be demonstrated during the 
first two postnatal weeks in rats (Presl et al., 1978). Present results demonstrating a delayed ovulatory failure induced by progesterone after the postnatal steroid sensitive period of sexual differentiation of the hypothalamus (Experiment 5) are thought to prove that the vulnerability of the development of control mechanisms of gonadotropin secretion is not limited to the period of morphological differentiation of the hypothalamus coinciding with the "damaging » postnatal effects of testosterone or estradiol (Dörner and Staudt, 1972). Ovulatory failure following long-term postnatal progesterone treatment suggests the "damaging " effects of similarly-timed hCG administration which, possibly, are mediated by stimulating ovarian and/or adrenal progesterone secretion.

In the meantime, any attempt to interpret the extracerebral mechanism of noxious and/or protective progesterone action is only speculative. The contemporary neuroendocrine concept of ovarian function control does not succeed in explaining a number of experimental data in rats and mice as for instance, a delay of the "critical » steroidsensitive period of the so-called neuronal competence of the hypothalamus by cortisol (Takasugi and Tomooka, 1976) or hCG treatment (Neumann and Buchholz, 1971). In contradistinction to the idea of an irreversible alteration of the sexual differentiation of the hypothalamus by early androgen or estrogen administration, a transplantation of intact ovaries at 120 days of age into neonatally androgenized female rats, ovariectomized at the age of 40 days, induces the ovulatory cycle (Kikuyama and Kawashima, 1966). These experiments, as well as prevention of early steroid-induced sterility in neonatal rats with thymocyte suspension (Kincl et al., 1965), ovarian « dysgenesis » after neonatal thymectomy (Nishizuka et al., 1973) or an ovarian cycle impairment during antithymocyte serum treatment in adult rats (Bukovsky ef al., 1977), suggest that in the development and control of the ovarian function both the neuroendocrine system and immune system participate in constituting a supersystem. It is tempting to speculate that long-lasting postnatal progesterone treatment does impair the normal development of the relationship between the differentiating immune system and the ovary (Bukovsky and Presl, 1979).

4th Workshop on « Development and maturation of the reproductive organs and functions" Luynes, France, octobre 1978.

Résumé. Un traitement de longue durée avec la progestérone, de rattes après la naissance, induit une absence d'ovulation précocement ou tardivement avec cestrus vaginal persistant, alors qu'une administration de courte durée est inefficace. Le début et l'incidence de l'absence d'ovulation apparaîssent dépendantes du commencement et de la durée du traitement et de la dose de progestérone. Abaisser la dose diminue l'action néfaste. Dimiriver la durée n'induit qu'une absence ovulatoire tardive et finalement diminue l'incidence de cette sorte d'activité néfaste de la progestérone. La durée nécessaire d'administration de la progestérone pour induire une absence d'ovulation précoce doit dépasser la période post-natale de sensibilisation aux stéroïdes au cours de la « sexualisation » de l'hypothalamus. De plus, un traitement de longue durée de progestérone a pour conséquence une absence ovulatoire tardive même si ce traitement débute après la fin de cette période critique. Nous concluons à partir de ces résultats que les effets nocifs et/ou protecteurs de la progestérone sur le développement du contrôle hypothalamique de la sécrétion de gonadotropine chez les rats femelles sont régulés par des mécanismes extra-cérébraux qui, pense-t-on, sont réalisés grâce aux relations entre un système immunitaire de différenciation ef l'ovaire. 


\section{References}

ARAI Y., GORSKI R. A., 1968. Protection against the neural organizing effect of exogenous androgen in the neonatal female rat. Endocrinology, 82, 1005-1009.

BUKOVSKY A., PRESL J., KRABEC Z., 1976. Pozdní anovulacní syndrom po protrahovaném podávání progesteronu $v$ casném postnatálním období krysy a jeho vztah $k$ folikulárni atresii. Cs. Gynek., 41, 281-285.

BUKOVSKY A., PRESL J., KRABEC Z., BEDNARIK T., 1977. Ovarian function in adult rats treated with antithymocyte serum. Experientia (Basel), 33, 280-281.

BUKOVSKY A., PRESL J., 1979. Ovarian function and the immune system. Med. Hypotheses (Montreal), 5, 415-436.

CAGNONI M., FANTINI F., MORACE G., GHETTI A., 1965. Failure of testosterone propionate to induce the "early-androgen » syndrome in rats previously injected with progesterone. $J$. Endocr., 33, 527-528.

DORFMAN R. I., KINCL F. A., 1963. A new function of progesterone, 171-176. In Reun. Anu. Soc. Mex. Nut. Endocrinol., Ixtapan de la Sal, México, Diciembre 6-7.

DÖRNER G., STAUDT J., 1972. Vergleichende morphologische Untersuchungen der Hypothalamusdifferenzierung bei Ratte und Mensch. Endokrinologie, 59, 152-155.

FELS E., 1976. Die Keimdrüsenfunktion der Ratte nach prae- oder postnataler Injektion verschiedener Hormone. Arch. Gynäk., 221, 103-118.

GORSKI R. A., 1971. Gonadal hormones and the perinatal development of neuroendocrine function, 237-290. In MARTINI L., GANONG W. F., Frontiers in neuroendocrinology, Oxford Univ. Press, New York.

GREENE R. R., BURRILL M. W., 1941. Posinatal treatment of rats with sex hormones : the permanent effects on the ovary. Amer. J. Physiol., 133, P302.

GREENSTEIN B. D., 1978. The role of hormone receptors in development and puberty. J. Reprod. Fert., 52, 419-426.

HEFNER L. J., VAN TIENHOVEN A., 1973. Effects of progesterone on uptake and retention of ${ }^{3} \mathrm{H}$-testosterone in the neonatal female rat. Neuroendocrinology, 12, 129-141.

KATO J., ONOUCHI T., OKINAGA S., 1978. Hypothalamic and hypophysial progesterone receptors : Estrogen-priming effect, differential localization, $5 x$-dihydroprogesterone binding, and nuclear receptors. J. Steroid Biochem., 9, 419-427.

KIKUYAMA S., KAWASHIMA S., 1966. Formation of corpora lutea in ovarian grafts in ovariectomized adult rats subjected to early postnatal treatment with androgen. Sci. Papers Coll. gen. Educ., Univ. Tokyo, 16, 69-74.

KINCL F. A., FOLCH PI A., HERRERA LASSO L., 1963. Efecto de hidrocortisona y progesterona administradas a ratas recien nacidas. Ciencia, Méx., 22, 135-136.

KINCL F. A., MAQUEO M., 1965. Prevention by progesterone of steroid-induced sterility in neonatal male and female rats. Endocrinology, 77, 859-862.

KINCL F. A., ORIOL A., FOLCH PI A., MAQUEO M., 1965. Prevention of steroid-induced sterility in neonatal rats with thymic cell suspension. Proc. Soc. exp. Biol. Med., 120, 252-255.

NEUMANN H. O., BUCHHOLZ R., 1971. Androgen-Sterilisierung der juvenilen weiblichen Ratte nach Behandlung mit humanem Chorion-Gonadotropin (HCG). Arch. Gynäk, 209, 416-419.

NISHIZUKA Y., SAKAKURA T., TANAKA Y., KOJIMI A., 1973. Disturbance in female reproductive function in neonatally thymectomized mice, 171-180. In PETERS $H$., The development and maturation of the ovary and its functions, Excerpta med., Amsterdam.

PRESL J., JIRASEK J., MIKULAS I., HORSKY J., 1967. Príspevek $k$ mechanismu vzniku anovulacní sterility po podání steroidu $\checkmark$ casné postnatální ontogenezi krysy. Cs. Gynek., 32, 658-660.

PRESL J., FIGAROVA V., HERZMANN J., RÖHLING S., 1975a. Changes in uptake of ${ }^{3} \mathrm{H}$-progesterone by female rat brain and pifuitary from birth to sexual maturity. Endocr. exp., 9, 51-58.

PRESL J., HERZMANN J., RÖHLING S., 1975b. Neúcinnost progesteronu na ukládání ${ }^{3} \mathrm{H}$-estradiolu do hypothalamu $v$ posłnatálním kritickém období vzniku prístí anovulacní sterility (tzv. early-estrogen syndromu) u krys. Cs. Gynek., 40, 751-754.

PRESL J., BUKOVSKY A., KRABEC Z., HERZMANN J., 1978. Unpublished results. 
SANO K., 1970. Effects of the administration of synthetic gestagens on the sex differentiation of female rats. Acta obstet. gynaec. jap., 17, 286-287.

SHIPLEY G., MEYER K., 1962. Effect of corticoids and progestins on pituitary gonadotrophic function in immature rats, 86-87. In Int. Congr. Horm. Steroids, Milan, Italy, May 14-19, Excerpta med. Found., Amsterdam.

SHIPLEY E. G., MEYER R. K., 1965. Effect of corticoids and progestins on pituitary gonadotropic functions in immature rats, 293-300. In MARTINI L., PECILE A., Hormonal steroids, biochemistry, phormacology and therapeutics, Proc. 1st int. Congr. Horm. Steroids, Vol. 2, Acad. Press, New York.

STUMPF W. E., SAR M., KEEFER D. A., MARTINEZ-VARGAS M. C., 1976. The anatomical substrate of neuroendocrine regulation as defined by autoradiography with ${ }^{3} \mathrm{H}$-estradiol, ${ }^{3} \mathrm{H}$ testosterone, ${ }^{3} \mathrm{H}$-dihydrotestosterone and ${ }^{3} \mathrm{H}$-progesterone, 46-56. In ANAND KUMAR T. C., Neuroendocrine regulation of fertility, Karger Basel.

TAKASUGI N., 1954. Veränderungen der hypophysären gonadotropen Aktivität der reifen, weiblichen Ratten, denen von Geburt an zwei gemischte Arten von hormonischen Steroiden injiziert wurden. J. Fac. Sci. Univ. Tokyo, Sect. IV Zool., 7, 153-159.

TAKASUGI N., TOMOOKA Y., 1976. Alteration of the critical period for induction of persistent œstrus by early postnatal treatment with gonadal steroids in neonatally cortisone-primed mice. J. Endocr., 69, 293-294. 